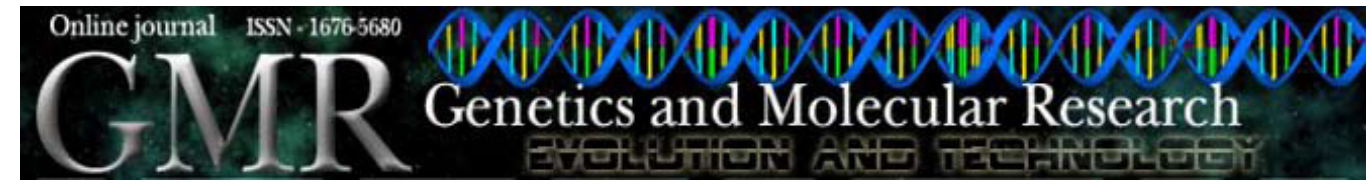

\title{
Silkworm salivary glands are not susceptible to Bombyx mori nuclear polyhedrosis virus
}

\author{
L.A. Dourado ${ }^{1}$, L.F.C. Ribeiro ${ }^{2}$, R.M.C. Brancalhão ${ }^{2}$, J. Tavares ${ }^{1}$, \\ A.R. Borges ${ }^{3}$ and M.A. Fernandez ${ }^{1}$ \\ ${ }^{1}$ Laboratório de Organização Funcional do Núcleo, \\ Departamento de Biologia Celular e Genética, \\ Universidade Estadual de Maringá, Maringá, PR, Brasil \\ ${ }^{2}$ Laboratório de Biologia Celular e Microtécnica, \\ Centro de Ciências Biológicas e da Saúde, \\ Universidade Estadual do Oeste do Paraná, Cascavel, PR, Brasil \\ ${ }^{3}$ Universidade do Estado de Mato Grosso, \\ Campus de Tangará da Serra, Tangara da Serra, MT, Brasil \\ Corresponding author: M.A. Fernandez \\ E-mail: aparecidafernandez@gmail.com
}

Genet. Mol. Res. 10 (1): 335-339 (2011)

Received October 8, 2010

Accepted January 8, 2011

Published February 22, 2010

DOI 10.4238/vol10-1gmr996

\begin{abstract}
A nuclear polyhedrosis virus isolated from infected Bombyx mori, BmNPV, was used to inoculate silkworms to determine salivary gland cell susceptibility. The salivary gland was removed from infected silkworms at different times post-inoculation and examined by light microscopy. The salivary gland cells did not exhibit any signs of BmNPV infection; however, fat body and tracheal cells, used as positive controls, showed characteristic cytopathological changes caused by BmNPV infection, which confirmed inoculum viability. The morphological distribution of tracheal branches and the basal lamina, which serves as a barrier to viral penetration, are apparently involved in this resistance to infection.
\end{abstract}

Key words: Mulberry silkworm; Baculoviridae; Tracheal system; Mandibular salivary glands; Fat body 


\section{INTRODUCTION}

Bombyx mori L., 1758 (Lepidoptera: Bombycidae) is very important economically as a silk producer in sericulture, and the insect is used as a model in biotechnology (Goldsmith et al., 2005). The mulberry silkworm life cycle is affected by a number of diseases caused by viruses, bacteria, fungi, and protozoa. These diseases occur in almost all the silkworm rearing areas, causing damage to the silkworm cocoon crop. The viral disease caused by the nuclear polyhedrosis virus (NPV), multiple subgroup, a genus of the family Baculoviridae, was identified in Paraná State, Brazil (Brancalhão et al., 2002).

NPV has a single double-stranded circular DNA, which is associated with the capsid proteins, forming the nucleocapsid. The nucleocapsid is enclosed within an envelope, forming the enveloped nucleocapsid, or virion. The viral subgroup called single NPV (SNPV) has only one nucleocapsid per envelope; in the case of more than one nucleocapsid, the subgroup is called multiple NPV (MNPV). This viral subgroup is considered to be more virulent mainly because, in the primary infection, the target midgut cells receive multiple nucleocapsids, whereas those infected by the S phenotype receive only one nucleocapsid. There is evidence for geographic viral variability in NPVs of the same species, and this variability could affect virulence (Hong et al., 2000; Fan et al., 2007). The B. mori NPV (BmNPV) geographic isolate in Brazil has polyhedra with virions that are enveloped singly and in groups (Brancalhão et al., 2009). However, based on DNA sequence data, the SNPV and MNPV subgroups did not conform to the phylogeny of the virus; thus, BmNPV is the virus type for SNPVs because of its production of predominantly single nucleocapsids (Rohrmann, 2008).

BmNPV infects the tegument, tracheae, midgut, fatty tissue, central nervous system, silk gland, and testis cells (Brancalhão and Ribeiro, 2003; Torquato et al., 2006; Pereira et al., 2008; Brancalhão et al., 2002, 2009), but nothing is known about the salivary gland susceptibility. This organ is responsible for saliva secretion in the larval stage, which moistens the food and lubricates and cleans the mouth-parts (Parthasarathy and Gopinathan, 2005). Anatomically, the salivary gland pair is an elongated tubular structure that arises from the mandibular segment to the thoracic segment (Parthasarathy and Gopinathan, 2005). Salivary glands have been used in cytogenetic studies because their cells undergo endomitosis, giving rise to nuclei containing giant polytene chromosomes, and they have proved to be suitable material for scientific investigation (David, 1975).

In this study, we determined the susceptibility of B. mori larval salivary gland cells to BmNPV, which is a geographic isolate from Paraná State, Brazil.

\section{MATERIAL AND METHODS}

Fourth-instar B. mori caterpillars obtained from the silk industry (Paraná, Brazil) were reared on fresh mulberry leaves (Morus sp) and maintained under conditions with controlled temperature, photoperiod and humidity.

BmMNPVs (GenBank accession No. EU251694) were obtained from previously infected B. mori caterpillars (Brancalhão, 2002). Inoculation was performed in fifth-instar larvae $24 \mathrm{~h}$ after ecdysis. They were fed on mulberry leaf discs, with a viral suspension at a concentration of $8 \times 10^{8}$ occlusion bodies $/ \mathrm{mL}$. Following ingestion, caterpillars were placed in individual plastic cups. Control caterpillars were treated with filtered water and handled similarly.

The salivary glands from four caterpillars were dissected at different hours post-inocula- 
tion (hpi), starting at $24 \mathrm{hpi}$ and up to the $216 \mathrm{hpi}$, at 24-h intervals. They were then fixed in DuBosq Brasil (Beçak and Paulete, 1976), dehydrated in ethanol and embedded in paraffin. Routine histological protocols were followed with time adaptations (Brancalhão et al., 2002). Sequential cuts were made with an Olympus CUT4055 microtome at thicknesses ranging between 5 and $7 \mu \mathrm{m}$. Sections were then stained with hematoxylin-eosin (Beçak and Paulete, 1976) for general analysis of the salivary glands. Azan stain, modified for viral occlusion bodies, was used for cytopathology and histopathology analyses (Hamm, 1966). Periodic acid Schiff was used to detect neutral and acid polysaccharides. The images were obtained with an Olympus BX60 photomicroscope.

\section{RESULTS AND DISCUSSION}

Salivary glands in inoculated and control mulberry silkworms had the same appearance - a pair of independently transparent tubular structures. These structures begin in the head and are connected to the mouth by an excretory pore, and they extend through the T1 thoracic segment, closely associated with the foregut (Parthasarathy and Gopinathan, 2005).

Cytopathological examination of salivary gland cells did not reveal any sign of BmNPV infection. The epithelium has a uniform composition, a unicellular layer consisting of a single cubic cell type. These secretory cells have a homogeneous cytoplasm, and, like other ectodermal glands, their nuclei are large and branched (Figure 1A).

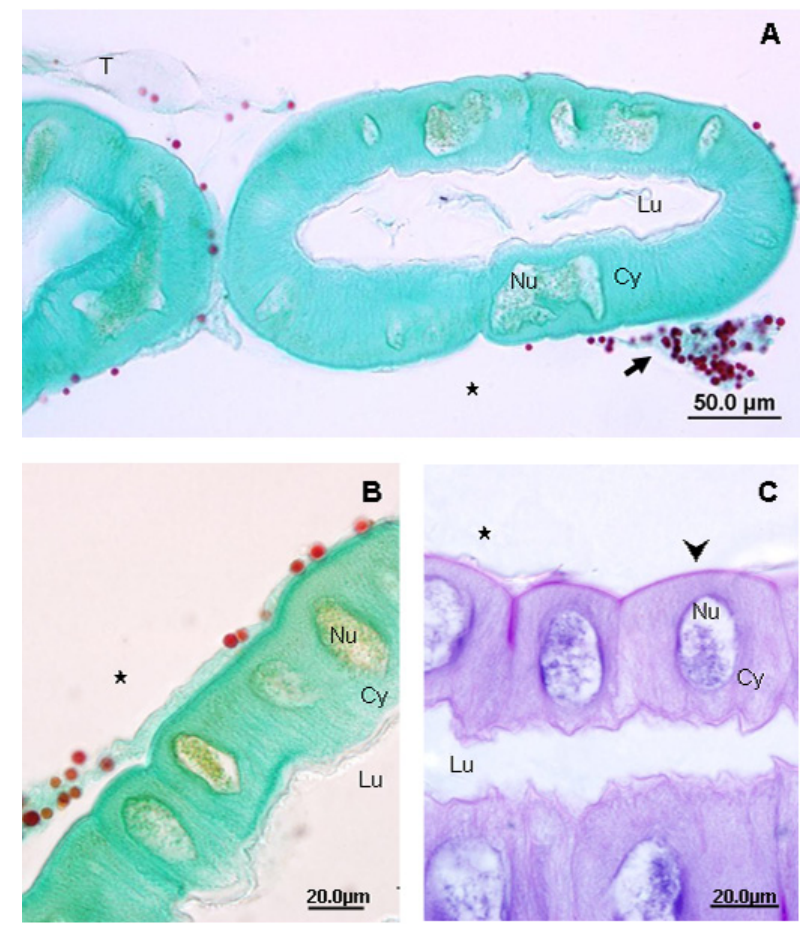

Figure 1. Bombyx mori salivary gland infected with B. mori nuclear polyhedrosis virus (BmNPV) (192 hours postinoculation). A. and B. Modified azan stain. C. Periodic acid Schiff stain. Epithelial cells show large and branched nuclei $(\mathrm{Nu})$, cytoplasm $(\mathrm{Cy})$ and salivary gland lumen $(\mathrm{Lu})$. BmNPV polyhedra (in red) are seen in the tracheal system (T), fat body (arrow) and extra-cellular medium (asterisk). The basal lamina is indicated by the arrowhead. 
During larval development, nuclei undergo endomitosis, and salivary gland cells grow by hypertrophy (Parthasarathy and Gopinathan, 2005). However, the fat body and tracheal system associated with the salivary gland were BmNPV-infected at 96 and 120 hpi, respectively, and they were used as positive controls (Figure 1B and C).

The literature describes the role of the tracheal system as an infection-spreading organ. Their branches penetrate deeply into target tissues, crossing the basal lamina and providing a conduit for virion (budded virions) dispersion (Barrett et al., 1998). The salivary gland tracheal system is observed only at the periphery (Figure 1C). Brancalhão et al. (2009) showed a similar tracheal organization in the anterior silk gland, where BmNPV infection did not occur, whereas the middle and posterior silk glands showed BmNPV infections initiating in the regions surrounding the tracheal insertions.

Moreover, the basal lamina, a fibrous extracellular matrix, is present in the majority of insect tissues, such as the salivary gland (Figure 1C, arrowhead). Studies have shown that the basal lamina organization and thickness seem to influence the passage of macromolecules, where it is able to act as a semipermeable barrier (Rahman and Gopinathan, 2004). Reddy and Locke (1990) investigated the behavior of gold particles in the basal lamina of Calpodes ethlius (Lepidoptera: Hesperiidae) larvae and showed that particles larger than $6 \mathrm{~nm}$ were retained in the silk gland, in the Malpighian tubule and in the muscle basal lamina. BmNPV virions have an approximate mean diameter of $95 \mathrm{~nm}$ and length of $315 \mathrm{~nm}$ (Brancalhão et al., 2009), making their passage through the salivary gland basal lamina difficult.

The tracheal system organization and the presence of the basal lamina make penetration of budded virions into the salivary gland difficult. Nevertheless, the lack of infection in certain cell types may also be caused by the differential expression of viral genes inserted in the host cell genome (Adams and McClintock, 1991; Brancalhão et al., 2002; Torquato et al., 2006).

\section{ACKNOWLEDGMENTS}

The authors would like to thank the sericulture companies of Paraná State for providing the Bombyx mori hybrid caterpillars, and also the Laboratório de Biologia Celular e Microtécnica, Universidade Estadual do Oeste do Paraná, Brazil. Research supported by FINEP/ Fundação Araucária, Secretaria de Estado da Ciência, Tecnologia e Ensino Superior, SETI, FUNDO PARANA, and the Science and Innovation Santander Banespa 2006 Prize.

\section{REFERENCES}

Adams JR and McClintock JT (1991). Baculoviridae. Nuclear Polyhedrosis Viruses. Part 1. Nuclear Polyhedrosis Viruses of Insects. In: Atlas of Invertebrate Viruses (Adams JR and Bonami JR, eds.). CRC Press, Florida, 89-180.

Barrett JW, Brownwright AJ, Primavera MJ and Palli SR (1998). Studies of the nucleopolyhedrovirus infection process in insects by using the green fluorescence protein as a reporter. J. Virol. 72: 3377-3382.

Beçak W and Paulete J (1976). Técnicas de Citologia e Histologia. Livros Técnicos e Científicos, Rio de Janeiro, 306.

Brancalhão RMC (2002). Vírus entomopatogênicos no bicho-da-seda: taxonomia e citopatologia causada por nucleopolyhedrovirus em células de Bombyx mori. Biotecnol. Ciênc. Desenvolv. 24: 54-58.

Brancalhão RMC and Ribeiro LFC (2003). Citopatologia da infecção causada pelo BmNPV no tegumento de Bombyx mori L., 1758 (Lepidoptera: Bombycidae). Arq. Ciênc. Vet. Zool. 6: 15-20.

Brancalhão RMC, Souza VBV and Soares MAM (2002). Infecção causada por nucleopolyhedrovirus nas células gordurosas de Bombyx mori L., 1758 (Lepidoptera: Bombycidae). Arq. Inst. Biol. 69: 57-63.

Brancalhao RMC, Torquato EF and Fernandez MA (2009). Cytopathology of Bombyx mori (Lepidoptera: Bombycidae) 
silk gland caused by multiple nucleopolyhedrovirus. Genet. Mol. Res. 8: 162-172.

David WAL (1975). The status of viruses pathogenic for insects and mites. Annu. Rev. Entomol. 20: 97-117.

Fan Q, Li S, Wang L, Zhang B, et al. (2007). The genome sequence of the multinucleocapsid nucleopolyhedrovirus of the Chinese oak silkworm Antheraea pernyi. Virology 366: 304-315.

Goldsmith MR, Shimada T and Abe H (2005). The genetics and genomics of the silkworm, Bombyx mori. Annu. Rev. Entomol. 50: 71-100.

Hamm JJ (1966). A modified azan staining technique for inclusion body viruses. J. Invertebr. Pathol. 8: 125-126.

Hong HK, Woo SD, Choi JY, Lee HK, et al. (2000). Characterization of four isolates of Bombyx mori nucleopolyhedrovirus. Arch. Virol. 145: 2351-2361.

Parthasarathy R and Gopinathan KP (2005). Comparative analysis of the development of the mandibular salivary glands and the labial silk glands in the mulberry silkworm, Bombyx mori. Gene Expr. Patterns 5: 323-339.

Pereira EP, Conte H, Ribeiro LF, Zanatta DB, et al. (2008). Cytopathological process by multiple nucleopolyhedrovirus in the testis of Bombyx mori L., 1758 (Lepidoptera: Bombycidae). J. Invertebr. Pathol. 99: 1-7.

Rahman MM and Gopinathan KP (2004). Systemic and in vitro infection process of Bombyx mori nucleopolyhedrovirus. Virus Res. 101: 109-118.

Reddy JT and Locke M (1990). The size limited penetration of gold particles through insect basal laminae. J. Insect Physiol. 36: 397-407.

Rohrmann GF (2008). Baculovirus Molecular Biology. National Library of Medicine (US), NCBI, Available at [http:// www.ncbi.nlm.nih.gov/bookshelf/br.fcgi?book=bacvir]. Accessed August 1, 2009.

Torquato EFB, Miranda Neto MH and Brancalhão RMC (2006). Nucleopolyhedrovirus infected central nervous system cells of Bombyx mori (L.) (Lepidoptera: Bombycidae). Neotrop. Entomol. 35: 70-74. 